\title{
Studi Pengaruh Tubing pada Performa In-Situ Well Repair Menggunakan Material Polyacrylamide dengan Coupled CFD-FEM
}

\author{
Arifa Nuriyani, Mas Irfan P. Hidayat, Sungging Pintowantoro, dan Sonny Irawan \\ Departemen Teknik Material, Fakultas Teknologi Industri, Institut Teknologi Sepuluh Nopember (ITS) \\ e-mail:masirfan.ph@gmail.com
}

\begin{abstract}
Abstrak-Tubing N80 sering digunakan sebagai production tubing, namun sering dilaporkan sering mengalami kebocoran akibat kontak langsung dengan fluida. Beberapa faktor penyebab kebocoran tubing ini yaitu perbedaan temperatur dan tekanan yang berlebih. Terdapat teknologi terbaru yaitu metode patch repair dengan menggunakan material non-logam, polimer superabsorbent. Polimer yang digunakan adalah Polyacrylamide, yang memiliki sifat unik dalam menyerap dan memelihara aliran fluida bertekanan. Akibat keterbatasan informasi tentang teknologi ini, maka mulai dikembangkan simulasi patch terhadap kebocoran tubing. Dalam penelitian ini akan menganalisis distribusi thermal dan deformasi pada tubing beserta patchnya, dengan temperatur operasi yang berbeda. Pembuatan geometri dan simulasi dilakukan dengan menggunakan software ANSYS Mechanical APDL Release 18.0 berdasarkan metode elemen hingga. Penelitian ini diharapkan dapat membantu industri minyak dan gas mensimulasikan kinerja patch terhadap kebocoran tubing, sebelum dilakukan secara praktik.
\end{abstract}

Kata Kunci-Leaking Repair, Patch, Polyacrylamide, Superabsorbent, Tubing

\section{PENDAHULUAN}

$\mathrm{I}_{\mathrm{n}}^{\mathrm{N}}$ NDUSTRI oil and gas melakukan pengeboran sumur untuk mendapatkan hidrokarbon dari reservoir menuju permukaan. Agar mutu hidrokarbon dari sumur ini terjaga dengan baik dan produksi terus tetap dilakukan, siklus lifetime sebuah sumur harus tetap dijaga. Terdapat 5 tahap proses pengeboran sumur yaitu eksplorasi, penilaian, pengembangan, produksi, dan pembuangan. Tahap produksi adalah tahap yang paling penting ketika dilakukan pengaliran hidrokarbon dari formasinya di dalam tanah. Dalam era ini, industri oil and gas melaporkan permasalahan yang cukup signifikan mempengaruhi produksi minyak bumi dan gas alam. Banyak industri oil and gas memiliki laporan bahwa adanya kebocoran pada casing, salah satu komponen yang mengalami kebocoran adalah tubing yang terekspos secara langsung dengan hasil produksi. Tubing yang mengalami kebocoran ini disebabkan oleh korosi, sand blasting, perbedaan temperatur, adanya shrinkage, dan tekanan yang berlebih. Kebocoran ini dapat memberikan efek bocornya hasil produksi dari tubing selama proses produksi berlangsung. Maka, tubing harus ditutup [1].

Namun, metode konvensional untuk memperbaiki sumur pada aplikasinya membutuhkan biaya yang mahal, banyak waktu, dan beresiko pada pengerjaan rig karena telah menghentikan atau harus melakukan shutdown pada sumur bor. Metode ini adalah dengan mengganti tubing produksi dan packer, lalu menjalankan kembali proses yang sempat terhenti. Selain itu, terdapat metode penambalan casing yang kurang praktis dan membuat tubing produksi beroperasi pengerjaan selanjutnya sulit dilakukan [2].

Polimer superabsorbent merupakan metode yang mulai dikembangkan dalam berbagai bidang, seperti pertanian, produk kebersihan, pengolahan air limbah, bahan penyegel, dan peningkatan perbaikan mutu minyak. Karena polimer ini memiliki sifat yang unik yaitu mampu menyerap dan memelihara sejumlah besar fluida yang bertekanan tertentu dan dapat digunakan untuk mencegah atau membatasi aliran fluida terhadap kebocoran pada tubing. Material polimer superabsorbent yang digunakan adalah Polyacrylamide [3]. Oleh karena itu, perlu adanya simulasi analis is numerik tentang polimer superabsorbent ini terhadap variasi temperatur aliran fluida berupa minyak mentah dari reservoir tanpa menghentikan atau shutdown proses produksi yang sedang berlangsung. Penelitian ini bertujuan untuk menganalisis pengaruh temperatur tubing terhadap kemampuan patch repair polyacrylamide dan temperatur optimum tubing yang paling tepat untuk dilakukan patch repair menggunakan polyacrylamide.

\section{METODE PENELITIAN}

\section{A. Peralatan}

Peralatan yang digunakan dalam penelitian berupa perangkat lunak (software) berbasis elemen hingga yaitu ANSYS Workbench Release 18.0 dengan modul Fluent dan Transient Structural yang digunakan untuk membuat permodelan geometri dan memodelkan simulasi in-situ well repair dengan menggunakan material polyacrylamide.

\section{B. Geometri}

Geometri yang digunakan pada penelitian ini adalah tubing 
N80 dengan permukaan berlubang sebanyak 5 buah. Masingmasing lubang memiliki diameter sebesar 0,15 inci. Posisi lubang pada tubing N80 yaitu 3 lubang berada di permukaan bawah berdasarkan tampak depan, dan 2 lubang berada di permukaan atas berdasarkan tampak belakang. Antarlubang memiliki jarak sebesar 36 inci.

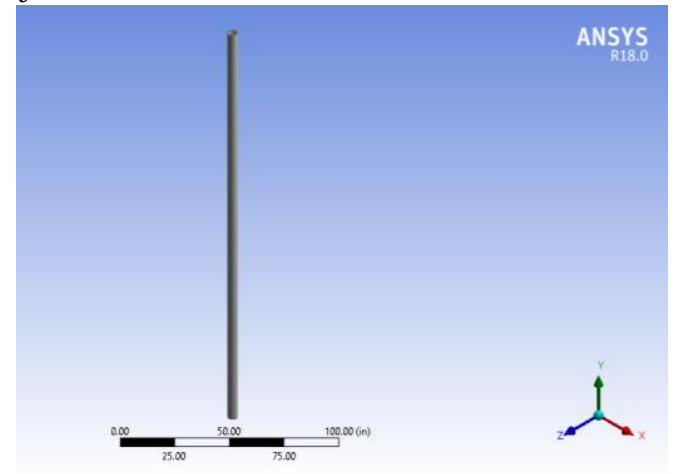

Gambar 1. Geometri Tubing N80 Tampak Depan

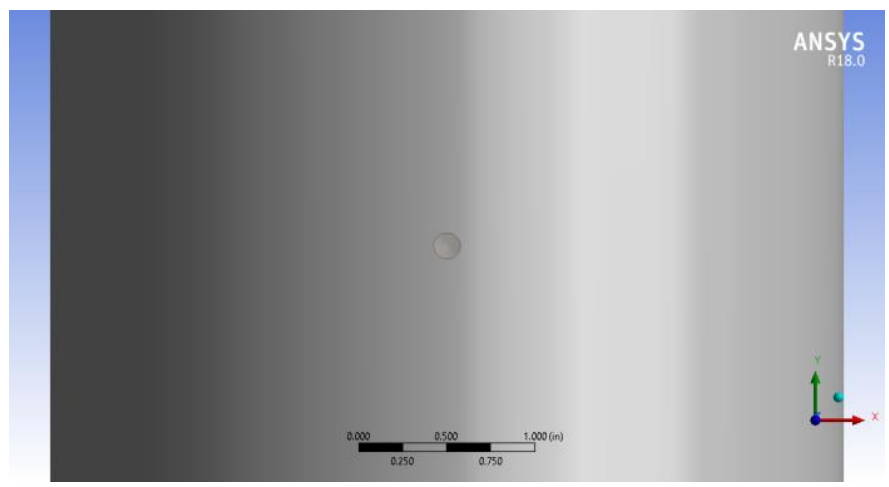

Gambar 2. Geometri Patch

\section{Material Properties}

Pada penelitian, material yang disimulasikan adalah tubing dengan grade N80. N80 adalah salah satu jenis baja karbon yang hanya memiliki sedikit unsur paduan. N80 memiliki spesifikasi sebagai berikut:

Tabel 1.

Spesifikasi Material Tubing N80 [4]

\begin{tabular}{cc}
\hline \hline Material Specifications & Value \\
\hline Density & $8030 \mathrm{~kg} / \mathrm{m}^{3}$ \\
Min. Yield Strength & $552 \mathrm{MPa}$ \\
Max. Yield Strength & $758 \mathrm{MPa}$ \\
Min. Tensile Strength & $689 \mathrm{MPa}$ \\
Max. Hardness & - \\
Total Elongation under Load $(\%)$ & 0,500 \\
Young Modulus & $207.000 \mathrm{MPa}$ \\
Spesific Heat & $502,48 \mathrm{~J} / \mathrm{kg} . \mathrm{K}$ \\
Thermal Conductivity & $16,27 \mathrm{~W} / \mathrm{m} . \mathrm{K}$ \\
Heat Transfer Coefficient & $150 \mathrm{~W} / \mathrm{m}^{2} . \mathrm{K}$ \\
OD & $4,5 \mathrm{inch}$ \\
Wall Thickness & $0,271 \mathrm{inch}$ \\
Length & $18 \mathrm{feet}$ \\
\hline \hline
\end{tabular}

Dalam penelitian ini, polyacrylamide digunakan sebagai material patch repair dengan sifat mekanik sebagai berikut:
Tabel 2.

Sifat Material Polyacrylamide [5]

\begin{tabular}{cc}
\hline \hline Material Specifications & Value \\
\hline Density & $1189 \mathrm{~kg} / \mathrm{m}^{3}$ \\
Young Modulus & $7111 \mathrm{~Pa}$ \\
Poisson's Ratio & 0,48 \\
Specific Heat & $3810 \mathrm{~J} / \mathrm{kg} . \mathrm{K}$ \\
Thermal Conductivity & $0,56 \mathrm{~W} / \mathrm{m} . \mathrm{K}$ \\
Molar Cohesive Energy & $39.800 \mathrm{~J} / \mathrm{mol}$ \\
\hline \hline
\end{tabular}

Selain itu terdapat sifat dari material fluida yang digunakan dalam penelitian ini, yaitu:

Tabel 3.

Sifat Minyak Mentah dan Gas Alam [6]

\begin{tabular}{cc}
\hline \multicolumn{2}{c}{ Minyak Mentah } \\
\hline Material Specifications & Value \\
Density & $960 \mathrm{~kg} / \mathrm{m}^{3}$ \\
Spesific Heat & $1880 \mathrm{~J} / \mathrm{kg} . \mathrm{K}$ \\
Thermal Conductivity & $0,12 \mathrm{~W} / \mathrm{m} . \mathrm{K}$ \\
Viscocity & $0,048 \mathrm{~kg} / \mathrm{m} . \mathrm{s}$ \\
Molecular Weight & $258,19 \mathrm{~kg} / \mathrm{kmol}$ \\
\hline & Gas Alam \\
Material Specifications & Value \\
Density & $0,6679 \mathrm{~kg} / \mathrm{m} 3$ \\
Standard State Enthalpy & $-7,489518 \mathrm{e}+007 \mathrm{~J} / \mathrm{kmol}$ \\
Thermal Conductivity & $0,0332 \mathrm{~W} / \mathrm{m} . \mathrm{K}$ \\
Viscocity & $1,087 \mathrm{e}-005 \mathrm{~kg} / \mathrm{m} . \mathrm{s}$ \\
Molecular Weight & $16,04303 \mathrm{~kg} / \mathrm{kmol}$ \\
\hline \hline
\end{tabular}

\section{Pengaturan Permodelan}

\section{1) Analisis Modul Fluent}

Dalam melakukan simulasi permodelan tubing N80, langkah pertama yang dilakukan adalah menentukan General Setup yaitu tipe pembebanan yang digunakan berdasarkan tekanan dan tidak bergantung pada waktu. Kecepatan fluida yang mengalir adalah absolut. Percepatan gravitasi bumi yang digunakan adalah $9,8 \mathrm{~m} / \mathrm{s} 2$. Nilai minus menunjukkan arah percepatan menjauhi pusat bumi.

Pada Setup selanjutnya, simulasi ini menggunakan model fluida multiphase dengan tipe volume of fluid, energy diaktifkan, dan viscous fluida dengan tipe laminar dalam tubing.

Material properties dapat diatur dalam menu setup ini, dengan menginput data dari Tabel 1. dan 2. sebagai solid material serta 3. sebagai fluid material. Setup dari Cell Zone Conditions dan Boundary Conditions disesuaikan dengan hasil meshing pada prosedur sebelumnya. Pada inlet, diatur dengan tipe velocity-inlet dan terdapat kondisi operasi berupa kecepatan 0,24 m/s (konstan) serta temperatur dalam tabulasi Thermal diinput sesuai dengan variabel bebas yang akan dianalisis. Sedangkan pada pengaturan nama interior menyesuaikan prosedur meshing sebelumnya. Pada outlet, simulasi ini diatur dengan tipe pressure-outlet. Kondisi wall diatur pada tabulasi thermal dengan nama material sebagai baja dengan nilai koefisien transfer panas sebesar $150 \mathrm{~W} / \mathrm{m}^{2} . \mathrm{K}$ dan ketebalan tubing sebesar 0,271 inci. Dynamic Mesh dan 
Reference Values dalam simulasi ini adalah pengaturan default.

Pada pengaturan Solution, metode analisis yang digunakan adalah pengaturan default dengan scheme berupa SIMPLE. Tabulasi controls juga diatur default.

\section{2) Analisis Modul Transient Structural}

Setelah melakukan analisis fluent, dapat dilakukan analisis thermal pada struktur tubing N80. Modul yang digunakan adalah transient structural dengan melakukan sistem coupling dari analis is fluent. Dalam analisis ini, pengaturan yang harus dilakukan yang pertama adalah meshing diperhalus dengan menggunakan refinement pada tubing, setelah itu meshing yang dilakukan pada analisis ini menggunakan fungsi curvature dengan kehalusan meshing sedang dengan menggunakan ukuran minimal meshing sebesar 0,01 inci pada tabulasi span angle center. Agar pada geometri patch terbentuk meshing yang halus, maka tabulasi inflation diatur dengan menggunakan smooth transition dengan maksimal sebanyak 15 layer.

Pada tabulasi transient, temperatur lingkungan di sekitar tubing sebesar variabel yang akan dianalisis. Analysis setting pada simulasi ini menggunakan step end time sebesar 22,86 detik.

\section{E. Kondisi Temperatur Inlet}

Variasi temperatur inlet yang diambil dari $323 \mathrm{~K}-673 \mathrm{~K}$ (323 K, 373 K, 423 K, 473 K, 523 K, 573 K, 623 K, dan 673 K).

Variasi temperatur inlet yang diambil bertujuan untuk menunjukkan daya lekat patch yang masih baik atau tidak pada temperatur tinggi atau lebih rendah dari titik leleh polyacrylamide. Geometri yang dibuat selanjutnya di-meshing hingga memperoleh sebanyak 264.446 elemen dan 496.602 node. Geometri ini sesuai dengan simulasi karena tidak terjadi error analysis selama software bekerja. Apabila elemen dan node dari meshing jumlahnya kurang dari nilai tersebut, hal ini akan menyebabkan kurangnya keakuratan dalam perhitungan dan bentuk nyata dari geometri kurang terbentuk. Hal tersebut telah terjadi ketika meshing. Apabila elemen dan node berjumlah lebih banyak, software secara otomatis melaporkan error analysis.

\section{F. Distribusi Thermal pada Analisis Modul Fluent}

Berdasarkan analis is data yang diperoleh, dapat ditunjukkan bahwa fluida mengalami temperatur loss selama fluida mengalir di sepanjang tubing. Hal ini terjadi karena adanya perpindahan panas secara konveksi dari fluida bertemperatur lebih tinggi menuju dinding tubing dan patch. Distribusi thermal yang tidak merata diakibatkan adanya perbedaan material properties antara baja dengan polimer, yaitu memiliki titik lebur yang berbeda. Baja memiliki titik lebur $>1.773 \mathrm{~K}$ dan polyacrylamide memiliki titik lebur $>573 \mathrm{~K}$, hal ini menyebabkan polyacrylamide akan mengalami defect pertama kali daripada tubing. Defect yang terjadi dapat berupa berkurangnya daya lekat patch, lepasnya patch, hingga patch meleleh. Sedangkan perpindahan panas antara tubing dan patch terjadi secara konduksi [7]. Tubing N80 yang memiliki konduktivitas thermal yang lebih tinggi daripada polyacrylamide, menunjukkan bahwa tubing N80 semakin baik dalam menghantarkan panas. Oleh karena itu pada analisis fluent ditunjukkan temperatur fluida mengalami distribusi thermal yang merata di sepanjang tubing daripada di sekitar patch.

Beberapa patch repair yang dilakukan memiliki dampak pada distribusi thermal. Patch repair yang terbentuk akan menyebabkan tonjolan ke dalam tubing dan menyebabkan penyempitan area tubing. Fluida yang mengalir akan mendorong dan bergesekan dengan tonjolan patch, hal ini menyebabkan temperatur di sekitar tonjolan patch meningkat akibat gesekan dan pemampatan volume fluida. Temperatur loss masing-masing variabel dapat ditunjukkan pada tabel dan grafik sebagai berikut:

Tabel 4.

Perbandingan Selisih Temperatur $(\Delta \mathrm{T})$ antar Titik

\begin{tabular}{|c|c|c|c|c|c|c|c|c|c|}
\hline \multicolumn{2}{|c|}{$\begin{array}{l}\text { Temperatur } \\
\text { Inlet }(\mathbf{K})\end{array}$} & 323 & 373 & 423 & 473 & 523 & 573 & 623 & 673 \\
\hline \multirow{13}{*}{ 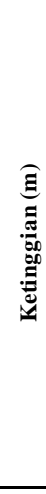 } & 0 & - & - & - & - & - & - & - & - \\
\hline & 0,911 & 5.18 & 16.88 & 28.2 & 39.51 & \multirow{2}{*}{51.32} & \multirow{2}{*}{62.31} & 73.7 & 84.9 \\
\hline & 5 & 5 & 9 & 2 & 4 & & & 4 & 3 \\
\hline & 1,822 & 1.82 & \multirow{2}{*}{6.267} & 9.39 & 14.28 & 18.01 & \multirow{2}{*}{23.48} & 30.5 & 34.3 \\
\hline & 9 & 9 & & 5 & 5 & 7 & & 8 & 8 \\
\hline & $\begin{array}{c}2,734 \\
4\end{array}$ & -2.31 & $\begin{array}{c}- \\
8.147\end{array}$ & -12.6 & $\begin{array}{c}- \\
18.21\end{array}$ & $\begin{array}{c}- \\
23.95\end{array}$ & $\begin{array}{c}- \\
29.93\end{array}$ & -38.3 & -42.7 \\
\hline & $\begin{array}{c}3,645 \\
9 \\
\end{array}$ & -3.95 & $\begin{array}{c}- \\
12.60 \\
\end{array}$ & -20.9 & $\begin{array}{c}- \\
29.85 \\
\end{array}$ & $\begin{array}{c}- \\
38.02 \\
\end{array}$ & $\begin{array}{c}- \\
46.83 \\
\end{array}$ & -55.4 & -64.2 \\
\hline & 4,557 & 0.17 & \multirow{2}{*}{0.547} & 0.93 & \multirow{2}{*}{1.265} & \multirow{2}{*}{1.671} & \multirow{2}{*}{2.057} & 2.45 & \multirow{2}{*}{2.74} \\
\hline & 4 & 1 & & 6 & & & & 6 & \\
\hline & 5,468 & 0.80 & \multirow{2}{*}{2.549} & 4.28 & \multirow{2}{*}{6.045} & \multirow{2}{*}{7.793} & \multirow{2}{*}{9.52} & 11.2 & 13.0 \\
\hline & 8 & 3 & & 2 & & & & 7 & 1 \\
\hline & 5,486 & 112 & - & 600 & - & - & - & 158 & 182 \\
\hline & 4 & -1.12 & 3.565 & -0.00 & 8.439 & 10.89 & 13.32 & -15.0 & -10.2 \\
\hline \multirow{2}{*}{\multicolumn{2}{|c|}{$\Delta T\left(T_{\text {in }}-T_{\text {out }}\right)$}} & 0.61 & \multirow{2}{*}{1.945} & 3.27 & \multirow{2}{*}{4.608} & \multirow{2}{*}{5.943} & \multirow{2}{*}{7.278} & 8.61 & 9.93 \\
\hline & & 2 & & 2 & & & & 3 & 7 \\
\hline
\end{tabular}

Tabel 5.

Nilai Deformasi Total

\begin{tabular}{ccc}
\hline \hline $\begin{array}{c}\text { Temperatur } \\
\text { Inlet }(\mathrm{K})\end{array}$ & $\begin{array}{c}\text { Deformasi Total } \\
\text { Minimum (meter) }\end{array}$ & $\begin{array}{c}\text { Deformasi Total } \\
\text { Maksimum (meter) }\end{array}$ \\
\hline 323 & 0,000018791 & 0,00061733 \\
373 & 0,000059599 & 0,001959 \\
423 & 0,00010049 & 0,0032998 \\
473 & 0,00013924 & 0,0046395 \\
523 & 0,00018123 & 0,0059797 \\
573 & 0,00022014 & 0,0073181 \\
623 & 0,00026273 & 0,0086574 \\
673 & 0,00029928 & 0,009994 \\
\hline \hline
\end{tabular}




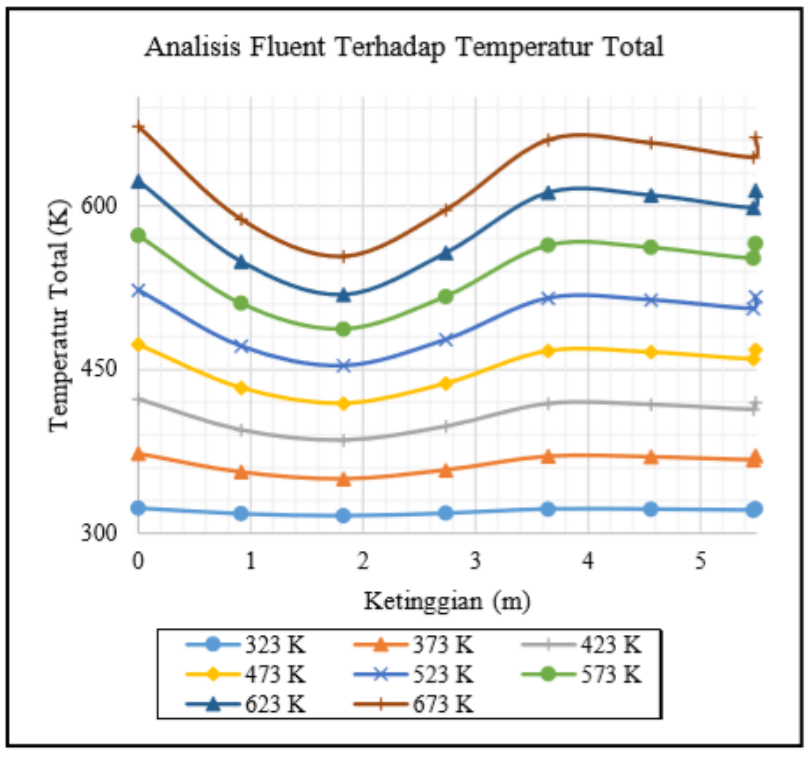

Gambar 3. Grafik Temperatur Total pada Analisis Fluent Selama Fluida Mengalir

Dari hasil analisis, temperatur loss terbesar terjadi pada temperatur inlet sebesar $673 \mathrm{~K}$ yaitu $9,937 \mathrm{~K}$ dari temperatur inlet menuju outlet. Temperatur tubing yang terlalu panas akan membuat kemampuan lekat patch menurun. Oleh karena itu, kondisi temperatur inlet di atas $573 \mathrm{~K}$ tidak dianjurkan.

\section{G. Distribusi Thermal pada Analisis Modul Transient Structural}

Deformasi total pada penelitian ini untuk menunjukkan seberapa besar deformasi akibat temperatur operasi yang dilakukan pada inlet. Tegangan von mises yang dianalisis merealisasikan tegangan thermal yang terjadi pada tubing N80 ketika diberi temperatur operasi tertentu pada inlet. Apabila kedua nilai ini semakin tinggi dari batas nilai dari material, akan menyebabkan menyebabkan terjadi thermal stress yang dapat menurunkan kualitas material itu sendiri [8] Hal ini akan menyebabkan adanya kavitasi lokal, keausan dan timbulnya korosi [9].

Berdasarkan masing-masing temperatur inlet, nilai terendah berada di temperatur inisiasi $323 \mathrm{~K}$ yaitu sebesar 0,000018791 meter untuk nilai minimum dan 0,00061733 meter untuk nilai deformasi maksimumnya. Sedangkan nilai deformasi tertinggi berada di temperatur inisiasi $673 \mathrm{~K}$ yaitu dengan nilai minimum 0,00029928 meter dan nilai maksimum 0,009994 meter. Hal ini dapat menunjukkan semakin besar temperatur inisiasi pada inlet maka semakin besar deformasi yang terjadi di sepanjang struktural.

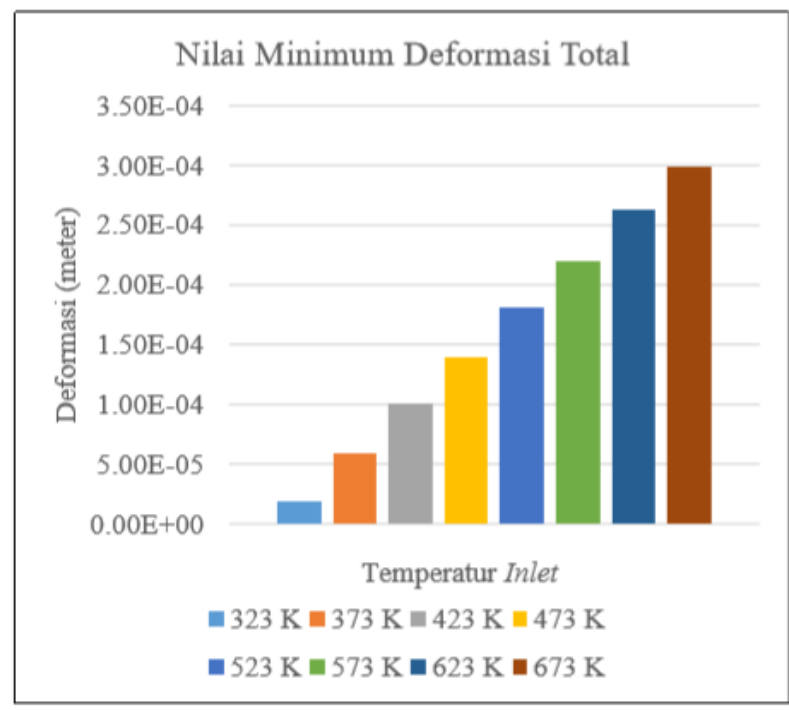

Gambar 4. Grafik Temperatur Operasi pada Inlet terhadap Nilai Minimum Deformasi

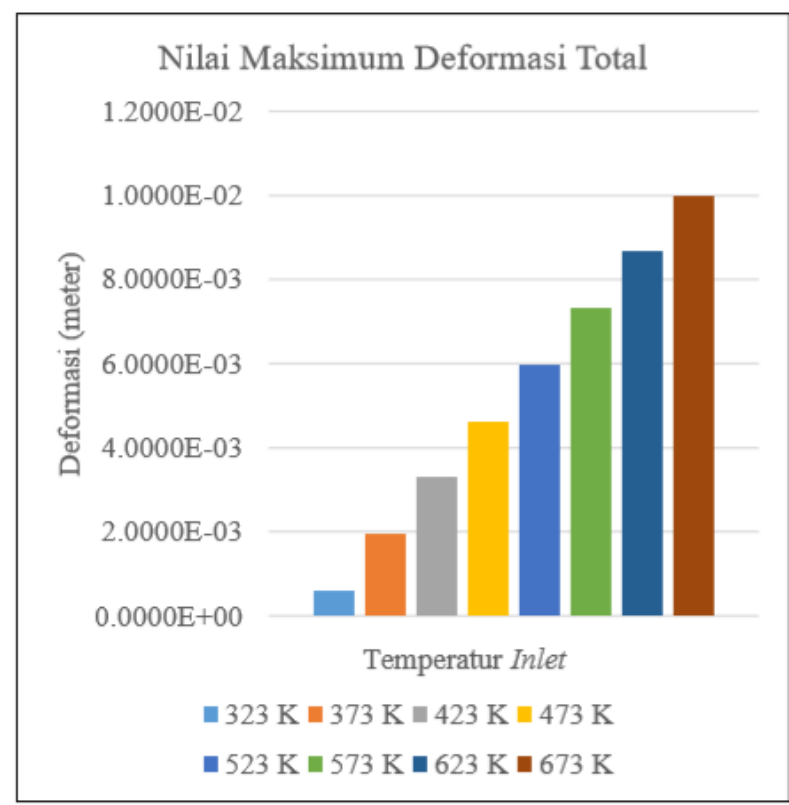

Gambar 5. Grafik Temperatur Operasi pada Inlet terhadap Nilai Maksimum Deformasi

Tegangan von mises digunakan untuk menunjukkan thermal stress pada tubing dan patch selama 22,86 detik fluida mengalir. Tegangan yang bervariasi ditunjukkan akibat adanya temperatur inisisasi yang berbeda. Berdasarkan analisis data pada sub-bab sebelumnya, tegangan terbesar berada di patch kedua. Tegangan terbesar terjadi diantara sambungan patch dan tubing. Hal ini dapat menunjukkan daya lekat patch terhadap tubing.

Berdasarkan masing-masing temperatur inlet, nilai terendah berada di temperatur inisiasi $323 \mathrm{~K}$ yaitu sebesar 42,983 MPa. Sedangkan nilai tegangan von mises tertinggi berada di temperatur inisiasi $673 \mathrm{~K}$ yaitu dengan nilai minimum 0,00029928 meter dan nilai maksimum 0,009994 meter. Hal ini juga dapat menunjukkan semakin besar temperatur inisiasi 
pada inlet maka semakin besar tegangan von mises yang terjadi di antara sambungan patch dan tubing.

Tabel 6.

Nilai Tegangan Von Mises Maksimal

\begin{tabular}{cc}
\hline \hline Temperatur Inlet $(\mathrm{K})$ & Tegangan Von Mises Maksimal (MPa) \\
\hline 323 & 42,983 \\
373 & 134,27 \\
423 & 230,74 \\
473 & 323,12 \\
523 & 416,8 \\
573 & 507,18 \\
623 & 596,75 \\
673 & 691,47 \\
\hline \hline
\end{tabular}

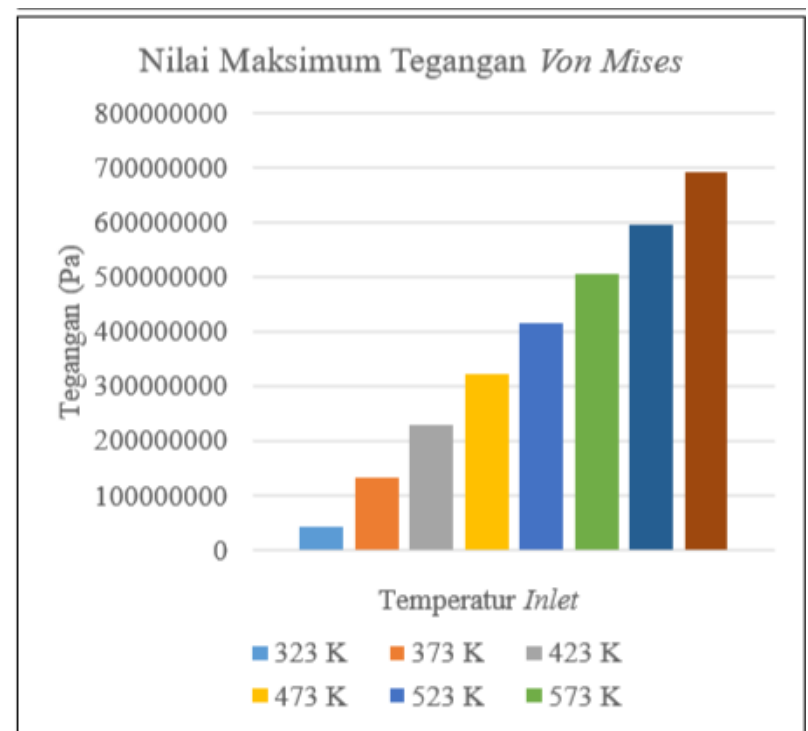

Gambar 6. Grafik Temperatur Operasi pada Inlet terhadap Nilai Maksimum Tegangan Von Mises

Nilai perpindahan dan tegangan von mises terbesar juga terjadi pada temperatur inlet $673 \mathrm{~K}$ ini dengan masing-masing nilai 0,009994 meter di ujung tubing dan 691,47 MPa terjadi di sekitar patch kedua. Karena tegangan dari polyacrylamide sebesar 665,8 $\mathrm{MPa}$, maka temperatur inlet lebih dari sama dengan $673 \mathrm{~K}$ tidak dianjurkan.

Dari hasil kedua analisis dengan modul fluent dan transient analysis ini, temperatur optimum yang dapat dioperasikan sekitar $323 \mathrm{~K}$ hingga $523 \mathrm{~K}$. Hal ini dapat didukung dengan studi sebelumnya milik Hidayat, et. al 2016 [10]. Hasil simulasi menunjukkan bahwa kemampuan casing untuk menahan tekanan formasi diturunkan seiring dengan banyaknya siklus thermal yang meluas, sehingga menyebabkan degradasi kekuatan casing pada aplikasi thermal. Sebagai rekomendasi dalam operasi secara praktik, disarankan agar temperatur kerja maksimum dari injeksi uap lebih baik berada di bawah $360^{\circ} \mathrm{C}$, misalnya $300^{\circ} \mathrm{C}$ atau setara dengan $573 \mathrm{~K}$. Pada temperatur ini, ditunjukkan bahwa casing memiliki tegangan thermal yang lebih rendah serta kemampuan yang lebih baik pada tekanan yang menurun.

\section{KESIMPULAN}

Temperatur tubing dapat mempengaruhi daya lekat patch repair polyacrylamide karena semakin tinggi temperatur tubing hingga melebihi titik leleh polyacrylamide, maka semakin berkurang daya lekat dan menurunnya kemampuan patch repair.

Temperatur optimum tubing yang paling tepat untuk dilakukan patch repair menggunakan polyacrylamide adalah di bawah titik leleh polyacrylamide yaitu $323 \mathrm{~K}$ hingga $523 \mathrm{~K}$, namun temperatur paling optimum adalah temperatur di bawah $323 \mathrm{~K}$ ditinjau dari nilai perpindahan dan tegangan von mises yang semakin kecil.

\section{LAMPIRAN}

\section{A. Perhitungan Kecepatan Alir Fluida}

Diketahui cross sectional area dari geometri tubing dalam simulasi sebes ar 12,304 in ${ }^{2}$. Untukflow rate proses pengeboran minyak mentah memiliki rentang nilai sebesar 1.000 hingga 1.200 barel/hari. Dalam simulasi ini, flow rate yang digunakan sebesar 1.050 barel/hari dengan konversi sebagai berikut:

$$
\begin{aligned}
& 1 \text { barrels } / \text { day }=0,0000018 \mathrm{~m}^{3} / \mathrm{s} \\
& 1.050 \text { barrels } / \text { day }=0,00189 \mathrm{~m}^{3} / \mathrm{s}
\end{aligned}
$$

Lalu konversi area sebesar:

$$
12,304 \mathrm{in}^{2}=0,00793804864 \mathrm{~m}^{2}
$$

Maka, diperoleh kecepatan alir fluida, sebesar:

$$
\begin{gathered}
\nu=\frac{\text { flow rate }}{\text { cross sectional area }}=\frac{0,00189 \mathrm{~m}^{\mathrm{a}} / \mathrm{s}}{0,00793804864 \mathrm{~m}^{2}} \\
\nu=0,238093779 \mathrm{~m} / \mathrm{s} \cong 0,24 \mathrm{~m} / \mathrm{s}
\end{gathered}
$$

B. Perhitungan Waktu Alir Fluida

$$
\begin{gathered}
v=\frac{s}{t} \\
t=\frac{s}{v} \\
t=\frac{5,4864 \mathrm{~m}}{0,24 \mathrm{~m} / \mathrm{s}} \\
t=22,86 \text { detik }
\end{gathered}
$$

\section{Perhitungan Tegangan Polyacrylamide}

Diketahui daya kohesi polyacrylamide sebesar $39.800 \mathrm{~J} / \mathrm{mol}$, memiliki densitas sebesar $1189 \mathrm{~kg} / \mathrm{m} 3$ dan volume sebesar 0,0047881 in $^{3} \quad\left(7,8311 \times 10-8 \mathrm{~m}^{3}\right)$. Berat molekul dari polyacrylamide yaitu $71,08 \mathrm{gr} / \mathrm{mol}$. 


$$
\begin{gathered}
\rho=\frac{m}{V} \\
m=\rho x \mathrm{~V} \\
m=1189 \times 7,8311 \cdot 10^{-8} \\
m=9,311.10^{-5} \mathrm{~kg} \\
m=0,09311 \mathrm{gram} \\
\frac{39800 \mathrm{~J}}{\mathrm{mot}} \times \frac{\mathrm{mot}}{71,08 \mathrm{gr}}=559,932 \mathrm{~J} / \mathrm{gr} \\
\frac{559,392 \mathrm{~J}}{\mathrm{gram}} \times 0,9311 \mathrm{gram}=52,136 \mathrm{~J}=52,136 \mathrm{~Pa} \cdot \mathrm{m}^{3} \\
\frac{52,136 \mathrm{~Pa} \cdot \mathrm{m}^{3}}{7,83311 \times 10^{-8} \mathrm{~m}^{3}}=665.759 .707,4 \mathrm{~Pa}=665,8 \mathrm{MPa}
\end{gathered}
$$

\section{UCAPAN TERIMA KASIH}

Penulis mengucapkan terima kasih kepada Direktorat Pendidikan Tinggi, Departemen Pendidikan dan Kebudayaan Republik Indonesia yang telah memberikan dukungan finansial melalui Beasis wa Bidik Misi tahun 2014-2018”.

\section{DAFTAR PUSTAKA}

[1] R. K. Khandka, Leakage Behind Casing. Norway: NTNU, 2007.

[2] J. R. Styler, J. W., Al-Suwailem, S. S., Akhnoukh, R. L. \& Leighton, A Unique Rigless Casing Leak Repair, Ghawar Field, Saudi Arabia. Saudi Arabia: Society of Petroleum Engineers, 2001.

[3] S. Ibrahim, M. A. b. \& Irawan, Absorption Properties of Superabsorbent Polymers for Sealing Tubing Leaks. Bandar Seri Iskandar: Universiti Teknologi Petronas, 2016.

[4] API, Specification for Casing and Tubing. Washington: American Petroleum Institute, 2005.

[5] C. Book, "Polyacrylamide," 2017. .

[6] H. Devold, Oil and Gas Produsction Handbook: An Introduction to Oil and Gas Production, Transport, Refining, and Petrochemical Industry. ABB Oil and Gas, 2013.

[7] C. J. Geankoplis, Transport Processes and Unit Operations, 3rd editio. New Delhi, 1997.

[8] W. D. Callister, Material Science and Engineering an Introduction. USA: John Wiley \& Sons, Inc, 2009.

[9] M. Z. Hidayat, M. I. P., Irawan, S. \& Abdullah, Effect of Casing Imperfection on the Casing Strength in Steam Injection Wells. Surabaya: IOP Publishing, 2017.

[10] M. Z. Hidayat, M. I. P., Irawan, S. \& Abdullah, Casing Strength Degradation in Thermal Environment of Steam Injection Wells. Surabaya: IOP Publishing, 2016. 